\title{
Pengaruh Konsentrasi Biourin Kelinci Terhadap Pertumbuhan Vegetatif Bayam Batik (Amaranthus Tricolor L. var. Giti Merah)
}

\author{
Sy. Hasan Agil ${ }^{1}$, Riza Linda ${ }^{1}$, Rafdinal $^{1}$ \\ Program studi Biologi, Fakultas MIPA, Universitas Tanjungpura, Jl. Prof. Dr. H. Hadari Nawawi, Pontianak, \\ Email: hasanagil23@gmail.com
}

\begin{abstract}
Batik spinach (Amaranthus tricolor L.) is a plant that is rich in nutrients and can be used as diabetes medicine and dysentery. Therefore, increasing the growth of batik spinach plants needs to be done, one of which is the use of organic fertilizers, which can be used as rabbit biourin. The use of rabbit urine is done because rabbit urine has a high nutrient content compared to other livestock. The aim of the study was to determine the effect of biourin on the growth of batik spinach (Amaranthus tricolor L.). The study used a Completely Randomized Design (CRD) with 5 levels of concentration treatment consisting of controls, $25 \mathrm{ml} / \mathrm{L}, 30 \mathrm{ml} / \mathrm{L}, 35 \mathrm{ml} / \mathrm{L}$, $40 \mathrm{ml} / \mathrm{L}$, with 5 replications. The results showed that the administration of rabbit biourin significantly affected plant height, number of leaves, wet weight, dry weight and ratio of roots / canopy. The concentration of $25 \mathrm{ml}$ / L gave the highest effect on the parameters of plant height, leaf number, root / crown ratio, wet weight, and dry weight.
\end{abstract}

Keywords : Batik spinach, Biourin, Rabbit, Vegetative Growth

\section{PENDAHULUAN}

Bayam batik (Amaranthus tricolor L.) merupakan tanaman holtikultura yang kaya akan kandungan nutrisi karena mengandung zat gizi antara lain: protein, karbohidrat, lemak, zat besi, vitamin A, B, C dan serat (Bandini dan Aziz, 1999). Bayam batik dapat digunakan sebagai obat kencing manis dan disentri serta kandungan antioksidan berupa betalain, karotenoid flavanoid dan polifenol dalam bayam batik diketahui telah jauh melampaui daun seledri dan rosella (Wijayasihati dan Wigato, 2016). Pengembangan tanaman bayam batik perlu dilakukan dalam aspek kualitas dan kuantitas melalui perbaikan secara ekstensifikasi dengan perluasan areal penanaman dan secara intensifikasi dengan menggunakan varietas unggul, penanaman dan pemupukan.

Penggunaan pupuk anorganik dapat meningkatkan produksi tanaman, tetapi penerapan dalam jangka panjang dapat menyebabkan kemunduran sifatsifat fisik, kimia dan biologi tanah maka dilakukan perbaikan pupuk yang dapat meningkatkan unsur hara, memperbaiki struktur tanah, dan meningkatkan kegiatan biologi melalui pemupukan dengan bahan organik, salah satunya dengan pemanfaatan limbah urin peternakan yang telah difermentasi atau biourin (Sutedjo 2010).

Menurut Nugroho (2017) biourin mengandung mikroorganisme yang dapat mempercepat proses dekomposisi dan meningkatkan ketersediaan unsur hara, terutama unsur nitrogen $(\mathrm{N})$, kalium $(\mathrm{K})$ dan fosfor $(\mathrm{P})$ sehingga dapat mengurangi penggunaan pupuk anorganik $(\mathrm{N}, \mathrm{P}, \mathrm{K})$ dan meningkatkan hasil tanaman secara maksimal.

Urin ternak yang dapat diolah menjadi biourin salah satunya adalah urin kelinci. Kandungan unsur hara makro utama pada urin kelinci berupa nitrogen $(\mathrm{N})$, fosfor $(\mathrm{P})$ dan kalium $(\mathrm{K})$ sangat tinggi dari pada kandungan unsur hara makro utama yang terdapat pada urin sapi dan domba. Kandungan unsur hara makro utama yang terdapat pada urin kelinci yaitu: N 2,72\%; P 1,1\%; K 0,5\% (Balitnak 2005 dalam Wiguna, 2010), sedangkan pada urin domba yaitu: N 1,35\%; P $0,05 \%$; K $2,10 \%$ dan pada urin sapi yaitu: N 1,00\%; P 0,50\%; K 1,50\% (Lingga, 2010).

Berdasarkan hasil penelitian terhadap urin kelinci yang dilakukan oleh Djafar et al., (2013) menunjukkan pemberian biourin kelinci berpengaruh nyata pada tinggi tanaman, jumlah daun, luas daun, bobot basah tanaman, bobot kering tanaman, dan produksi per plot pada tanaman sawi. Penelitian urin kelinci semakin diperkuat dengan adanya penelitian Nugraheni dan Paiman, (2010) menyatakan bahwa biourin kelinci dengan konsentrasi $300 \mathrm{ml} / \mathrm{L}$ air menunjukkkan pertumbuhan dan hasil tanaman tomat yang paling baik.

Penggunaan biourin kelinci yang difermentasi sebagai salah satu potensi alternatif pendukung pertumbuhan tanaman bayam batik menjadikan penelitian ini perlu dilakukan. Penggunaan biourin 
dengan konsentrasi tertentu diharapkan mampu membuat tanaman tumbuh dengan baik.

\section{BAHAN DAN METODE}

\section{Waktu dan Penelitian}

Penenlitian dilaksanakan dari bulan Januari sampai dengan Maret 2018 di Laboratorium Biologi dan Rumah Kaca Fakultas Matematika dan Ilmu Pengetahuan Alam Universitas Tanjungpura Pontianak. Analisa tanah dan biourin dilakukan di Laboratorium Kimia dan Kesuburan Tanah Fakultas Pertanian Universitas Tanjungpura Pontinak.

\section{Alat dan Bahan}

Alat-alat yang digunakan dalam penelitian ini yaitu botol $1500 \mathrm{ml}$, , jerigen, gelas ukur, alat tulis, cangkul, sekop kecil, termohigrometer, terpal, handsprayer, kamera hp, timbangan analitik, saringan tanah, kertas label, oven, penggaris, soiltester dan timbangan analitik.

Bahan yang digunakan dalam penelitian ini yaitu bayam batik (Amaranthus tricolor L.), tanah gambut, polibag 14,5 x 19,5 cm, air, urin kelinci, EM4 (Effective microorganism), tetes tebu (molases), Urea, KCL dan SP36

\section{Rancangan Penelitian}

Rancangan yang digunakan dalam penelitian ini adalah Rancangan Acak Lengkap (RAL) yang terdiri dari 5 perlakuan yaitu : Kontrol, $25 \mathrm{ml} / 1$ liter air, $30 \mathrm{ml} / 1$ liter air, $35 \mathrm{ml} / 1$ liter air, dan $40 \mathrm{ml} / 1$ liter air

\section{Prosedur Kerja}

\section{Persiapan Media Tanam}

Tanah yang digunakan adalah tanah gambut yang diambil dari kedalaman 0-20 cm, lalu dikering anginkan, dibersihkan dari sampah serta sisa-sisa tanaman, tanah diayak menggunakan ayakan kawat berdiameter $5 \mathrm{~mm}$, tanah hasil ayakan dicampur dengan kapur dolomit sebanyak $1,2 \mathrm{~kg}$ berdasarkan perhitungan kebutuhan kapur/polibag dan Selanjutnya dimasukkan ke dalam polibag, masing-masing polibag di isi dengan 1,6 kg tanah lalu diinkubasi selama 2 minggu hingga $\mathrm{pH}$ mendekati netral $( \pm 7)$.

\section{Pembuatan Biourin}

Urin kelinci yang telah ditampung ke dalam botol penampung, kemudian dipindahkan ke jerigen yang berukuran $5 \mathrm{~L}$ sebanyak $1,6 \mathrm{~L}$ urin untuk proses fermentasi, ditambahkan $16 \mathrm{~mL}$ EM4 dan dimasukkan tetes tebu sebanyak $120 \mathrm{ml}$, diaduk hingga rata kemudian wadah ditutup dengan rapat dan difermentasi selama 14 hari. Pada hari ke 15 dilakukan pengadukan biourin yang bertujuan untuk mengurangi kadar ammonia (Huda, 2013).

\section{Penanaman}

Penanaman dilakukan dengan menebar biji bayam sebanyak 5 biji per polibag pada pagi atau sore hari, hasil semaian yang pertumbuhannya baik dipilih 1 tanaman sebagai tanaman uji dan sisanya dicabut. Tanaman yang dipilih sebagai tanaman uji, memiliki tinggi sekitar $10 \mathrm{~cm}$ dengan 3 helaian daun atau lebih, waktu penyemaian dilakukan 14 hari, setelah itu diberi pupuk dasar berupa NPK dengan dibenamkan kedalam tanah dengan jarak 5 $\mathrm{cm}$ antara tanaman dan lubang dengan dosis Urea 2 gram, Kcl 4 gram, Sp36 3 gram (Bandini dan Azis 1999).

\section{Aplikasi Biourin}

Aplikasi biourin dilakukan dengan pengenceran sesuai dengan masing-masing perlakuan yaitu kontrol, $25 \mathrm{ml} / \mathrm{L}, 30 \mathrm{ml} / \mathrm{L}, 35 \mathrm{ml} / \mathrm{L}$, dan $40 \mathrm{ml} / \mathrm{L}$, dilarutkan dalam air sampai menjadi $1000 \mathrm{ml}$, pemberian pupuk diberikan 14 HST. Pemberian pupuk dilakukan dengan penyemprotan pada bagian tanaman sampai basah merata. Frekuensi pemberian pupuk setiap 5 hari sekali pada pagi hari pukul 08.00-010.00 WIB atau sore hari pukul 15.00-17.00 WIB (Lingga, 2010).

\section{Pemeliharaan Tanaman}

Pemeliharaan tanaman meliputi penyiraman yang dilakukan 1 kali sehari, yaitu pada pagi hari atau sore hari. Penyiangan gulma dilakukan dengan cara mencabut gulma yang tumbuh disekitar tanaman (Bandini dan Azis 1999).

\section{Pengukuran Lingkungan dan Kesuburan Tanah.} Pengamatan terhadap kondisi lingkungan disekitar tanaman serta parameter kesuburan media tanam meliputi :

a. Suhu udara $\left({ }^{\circ} \mathrm{C}\right)$

Pengukuran dilakukan satu minggu sekali dengan menggunakan termohigrometer yang dilakukan pada pagi hari pukul 06.00-08.00 WIB, siang hari pukul 12.00-13.00 WIB dan sore hari pukul 16.00-18.00 WIB.

b. Kelebapan udara relatif $(\%)$

Pengukuran dilakukan satu minggu sekali dengan menggunakan termohigrometer yang dilakukan pada pagi hari pukul 06.00-08.00 WIB, siang hari pukul 12.00-13.00 WIB dan sore hari pukul 16.00-18.00 WIB. 


\section{c. Analisis tanah}

Tanah dianalisis pada awal penelitian sebelum penanaman meliputi $\mathrm{pH}$, kandungan $\mathrm{N}, \mathrm{P}, \mathrm{K}, \mathrm{C}$ organik, fisika dan kimia tanah, dan nisbah $\mathrm{C} / \mathrm{N}$.

d. Analisis biourin

Biourin dianalisis pada awal penelitian sebelum penanaman meliputi $\mathrm{pH}, \mathrm{C}$ organik, $\mathrm{Ca}, \mathrm{Mg}$ dan kandungan $\mathrm{N}, \mathrm{P}, \mathrm{K}$.

\section{Parameter Pengamatan}

Setelah tanaman memasuki masa panen (35 HST), seluruh bagian tanaman diambil kemudian dilakukan pengukuran sesuai parameter pertumbuhan yang diamati yaitu :

a. Tinggi tanaman $(\mathrm{cm})$.

Pengukuran tinggi tanaman dilakukan dengan menggunakan penggaris, pengukuran dimulai dari pangkal batang sampai titik tumbuh.

b. Jumlah daun (helai).

Penghitungan Jumlah daun dilakukan dengan menghitung keseluruhan jumlah daun yang ada pada tanaman tersebut kecuali daun yang masih belum membuka sempurna.

c. Berat basah akar dan tajuk (gram).

Berat basah tanaman diukur dengan menimbang tanaman dalam keadaan segar dengan cara menimbang masing-masing akar dan tajuk menggunakan timbangan analitik.

d. Berat kering akar dan tajuk (gram).

Berat kering tanaman diukur pada akhir penelitian, yaitu tanaman dikeringkan dalam oven dengan suhu $60-70^{\circ} \mathrm{C}$. hingga mendapatkan berat kering yang konstan, berat kering diukur dengan cara menimbang masingmasing bagian akar dan tajuk dengan menggunakan timbangan analitik.

e. Rasio akar/tajuk

Rasio akar/tajuk dihitung pada akhir penelitian dengan menggunakan rumus sebagai berikut :

$$
\text { Rasio akar/tajuk }=\frac{\text { Berat kering tajuk }}{\text { Berat kering akar }}
$$

\section{Analisis Data}

Data pertumbuhan dianalisis dengan ANOVA satu jalur taraf uji 5\% menggunakan SPSS 18 Bila terdapat pengaruh nyata dilanjutkan dengan uji Duncan pada taraf uji 5\% (Gaspers, 1991).

\section{Hasil dan Pembahasan \\ Hasil}

Kualitas Biourin Kelinci diuji berdasarkan standar sifat fisik dan komponen kimia. Sifat fisik yang diamati adalah warna dan aroma. Perubahan warna biourin kelinci terjadi selama 14 hari dari warna awal kuning kehitaman menjadi kecoklatan dan Biourin beraroma khas tapai (Gambar 1).

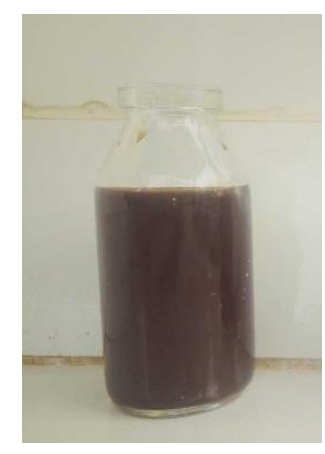

a

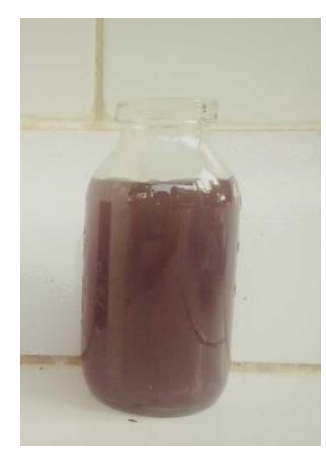

b
Gambar 1 Perubahan Warna Biourin a. hari pertama $b$. hari ke 14

Hasil analisis biourin menunjukkan untuk parameter C-organik, unsur hara makro berupa NPK dan nilai $\mathrm{pH}$ yang diuji tidak berbeda jauh dengan hasil penelitian yang telah dilakukan Afrianto (2015) untuk hasil kandungan yang di dapatkan adalah C-Organik 2,45 \%, Nitrogen (N) $1,81 \%$, Fosfor (P) 0,14\% dan Kalium (K) 0,32\% dan nilai $\mathrm{Ph}$ 5,62 sedangkan hasil penelitian biourin kelinci Afrianto (2015) nilai kandungan untuk COrganik adalah 0,62 dan kandungan unsur hara makro untuk nitrogen 1,76, fosfor 0,23 , dan Kalium 0,50 dan untuk nilai $\mathrm{pH}$ adalah; 9,14 (Tabel 1).

Tabel 1 Analisis Biourin Kelinci

\begin{tabular}{clccc}
\hline $\mathrm{No}$ & Parameter & Satuan & Biourin Kelinci & Biourin Kelinci Afrianto (2015) \\
\hline 1 & $\mathrm{C}-$ Organik & $\%$ & 2,45 & 0,62 \\
2 & $\mathrm{pH}$ & & 5,62 & 9,14 \\
3 & $\mathrm{Mg}$ & $\%$ & 0,05 & - \\
4 & $\mathrm{Ca}$ & $\%$ & 0,04 & - \\
5 & $\mathrm{~N}$ & $\%$ & 1,81 & 1,76 \\
6 & $\mathrm{P}_{2} \mathrm{O}_{5}$ & $\%$ & 0,14 & 0,23 \\
7 & $\mathrm{~K}_{2} \mathrm{O}$ & $\%$ & 0,32 & 0,50 \\
\hline
\end{tabular}


Analisis uji ANOVA digunakan untuk mengetahui pengaruh biourin kelinci terhadap pertumbuhan bayam pada lima perlakuan: A (Kontrol), B (25 $\mathrm{ml} / \mathrm{L}), C(30 \mathrm{ml} / \mathrm{L}), \mathrm{D}(35 \mathrm{ml} / \mathrm{L}), \mathrm{E}(40 \mathrm{ml} / \mathrm{L})$. Berdasarkan analisis, pemberian biourin kelinci berpengaruh nyata pada 5 variabel perlakuan yaitu tinggi tanaman $\left(\mathrm{F}_{4,20}=11,134, P=0,000\right.$; ANOVA), Jumlah daun $\left(\mathrm{F}_{4,20}=5,72, P=0,004\right.$; ANOVA), berat basah $\left(\mathrm{F}_{4,20}=9,765, P=0,000\right.$; ANOVA), berat kering $\left(\mathrm{F}_{4,20}=2,938, P=0,046\right.$; ANOVA), Rasio Akar/Tajuk $\left(\mathrm{F}_{4,20}=4,083, P=\right.$ 0,014; ANOVA) (Tabel 2)

Tabel 2 Nilai Rerata Pengukuran Pertumbuhan Tanaman Bayam Batik yang telah diberi perlakuan Biourin kelinci Setelah 35 HST (Hari Setelah Tanam)

\begin{tabular}{|c|c|c|c|c|c|c|}
\hline No & Perlakuan & $\begin{array}{l}\text { Tinggi } \\
\text { Tanaman } \\
(\mathrm{cm})\end{array}$ & $\begin{array}{l}\text { Jumlah daun } \\
\text { (helai) }\end{array}$ & $\begin{array}{l}\text { Berat Basah } \\
\quad \text { (gr) }\end{array}$ & $\begin{array}{c}\text { Berat } \\
\text { Kering (gr) }\end{array}$ & $\begin{array}{c}\text { Rasio } \\
\text { Akar/Tajuk }\end{array}$ \\
\hline 1 & A & $27,6 \pm 3,31^{\mathrm{a}}$ & $15,8 \pm 0,96^{\mathrm{a}}$ & $16,9 \pm 1,32^{a}$ & $2,2 \pm 0,35^{\mathrm{a}}$ & $0,4 \pm 0,08^{\mathrm{a}}$ \\
\hline 2 & B & $45,6 \pm 3,31^{b c}$ & $26,0 \pm 3,43^{b}$ & $22,6 \pm 0,65^{b}$ & $2,7 \pm 0,61^{a b}$ & $1,0 \pm 0,18^{b}$ \\
\hline 3 & $\mathrm{C}$ & $54,3 \pm 2,78^{\mathrm{c}}$ & $29,8 \pm 3,45^{\mathrm{b}}$ & $24,1 \pm 0,94^{\mathrm{b}}$ & $3,5 \pm 0,86^{\mathrm{b}}$ & $1,0 \pm 0,25^{\mathrm{b}}$ \\
\hline 4 & D & $40,7 \pm 0,81^{\mathrm{b}}$ & $22,8 \pm 1,24^{\mathrm{ab}}$ & $21,3 \pm 0,59^{b}$ & $2,9 \pm 0,19^{\mathrm{ab}}$ & $0,5 \pm 0,56^{\mathrm{a}}$ \\
\hline 5 & E & $50,6 \pm 4,02^{c}$ & $28,8 \pm 3,78^{\mathrm{b}}$ & $23,4 \pm 0,83^{b}$ & $3,5 \pm 0,98^{\mathrm{b}}$ & $0,9 \pm 0,20^{\mathrm{b}}$ \\
\hline
\end{tabular}

Keterangan: Angka-angka yang diikuti huruf yang sama pada baris atau kolom yang sama tidak berbeda nyata tidak berbeda nyata pada uji Duncan taraf 5\%

\section{Pembahasan}

Biourin kelinci yang difermentasi selama 14 hari mengalami perubahan warna akhir coklat kehitaman (Gambar 4.1) dan aroma khas tapai. Perubahan aroma dan warna yang dihasilkan biourin kelinci menandakan berlangsungnya proses fermentasi. Fermentasi menunjukkan adanya aktivitas mikroorganisme dalam proses dekomposisi bahan organik. Keberhasilan fermentasi bahan organik urin kelinci yang menunjukkan dari warna kuning kehitaman menjadi kecoklatan juga terjadi pada penelitian Nugraheni dan Paiman (2010). Menururt Kurniadinata (2008) Biourin siap diaplikasikan pada tanaman jika tingkat kematangannya sempurna dengan bau khas fermentasi serta cairan yang dihasilkan berwarna coklat kehitaman.

Nilai hasil kandungan Nitrogen biourin kelinci apabila dibandingkan dengan hasil kandungan Nitrogen biourin penelitian Afrianto (2015) memiliki nilai yang tidak berbeda jauh untuk nilai Nitrogen biourin kelinci adalah 1,81\% sedangkan hasil nilai analisis biourin kelinci Afrianto (2015) adalah $1,76 \%$ hal ini diduga mikroorganisme yang terdapat di EM-4 yang termasuk dalam genusgenus Pseudomonas dan Streptomyces dapat menghasilkan Nitrogen dalam bentuk nitrit dan nitrat selain itu peranan bakteri fotosintetik juga dapat memfiksasi Nitrogen sehingga dapat mensuplai Nitrogen yang ada pada biourin. Menurut Hans (1994) bakteri fotosintetik dapat memfiksasi Nitrogen dalam bentuk amonium yang mana amonium nantinya akan dioksidasi menjadi Nitrit dan Nitrat oleh bakteri yang tergolong dalam genus Pseudomonas dan Streptomyces. Selain itu, nilai $\mathrm{pH}$ juga dapat mempengaruhi kandungan unsur Nitrogen pada biourin kelinci yang dapat mempengaruhi kinerja mikroorganisme. Menurut Suriawira (2010) bakteri akan hidup optimum pada $\mathrm{pH}$ yang mendekati netral sedangkan hasil nilai $\mathrm{pH}$ pada biourin kelinci berada pada antara nilai optimum yaitu antara 5-7. Sehingga kinerja bakteri yang berperan dalam mengoksidasi amoniak optimal.

Kandungan unsur fosfor pada biourin kelinci memiliki nilai $0,14 \%$ yang tidak berbeda jauh terhadap penelitian Afrianto (2015) yaitu 0,23\% .Hal ini dikarenakan adanya kandungan unsur hara Nitrogen pada urin kelinci dikarenakan semakin tinggi kandungan Nitrogen maka mikroorganisme yang merombak Fosfor semakin meningkat. Menurut Chapelle (2001) bahwa perumbuhan mikroorganisme membutuhkan Fosfor untuk membangun sel, seperti pembentukan protoplasma dan inti sel dan diperkuat oleh Parnata (2004) menyatakan bahwa semakin tinggi nitrogen maka multiplikasi mikroorganisme yang merombak Fosfor akan meningkat.

Kandungan unsur hara Kalium biourin kelinci hasil analisis yaitu $0,32 \%$ dan tidak berbeda jauh dari pada kandungan unsur hara kalium hasil penelitian yang telah dilakukan Afrianto (2015) yaitu 0,50 \% . Kandungan unsur hara kalium pada biourin terbentuk karena adanya mikroorganisme yang bekerja dalam kondisi anaerob Menurut Nugroho (2010) bahwa mikroorganisme dapat bekerja 
secara optimum jika dalam lingkungan kedap udara (anaerob) sehingga ada udara masuk mikroorganisme tidak dapat bekerja secara maksimal. Suriawira (2011) menyatakan kehadiran bakteri dan aktivitasnya sangat mempengaruhi peningkatan kalium, mikroorganisme menggunakan kalium dalam bahan substrat sebagai katalisator, dengan adanya mikroorganisme dan aktivitasnya akan sangat berpengaruh terhadap peningkatan kalium. Kalium dapat diikat dan disimpan dalam sel oleh bakteri dan jamur.

Hasil penelitian menunjukkan bahwa perbandingan variasi konsentrasi biourin kelinci memberikan pengaruh terhadap pertumbuhan tanaman bayam batik. Perlakuan pupuk konsentrasi $25 \mathrm{ml} / \mathrm{L}$ memberikan hasil yang terbaik terhadap lima variabel perlakuan: tinggi tanaman, jumlah daun, berat basah, berat kering, dan rasio akar/tajuk. Hasil dalam penelitian ini sesuai dengan hasil penelitian terdahulu yang dilakukan oleh Djafar et al., (2013) menunjukkan pemberian biourin kelinci terhadap tanaman sawi (Brassica chinensis) berpengaruh nyata pada tinggi tanaman, jumlah daun, luas daun, berat basah, dan berat kering. Hal ini diduga dengan pemberian biourin kelinci mampu mensuplai kebutuhan unsur hara pada tanman bayam batik.

Kandungan unsur hara dalam biourin menyebabkan terpacunya pembelahan sel dan pemanjangan sel pada meristem apikal sehingga akan mempengaruhi pertumbuhan tinggi tanaman. Jumlah daun berkaitan dengan tinggi tanaman. Menurut Prawiranata et al, (1981) semakin tinggi tanaman maka semakin banyak nodus tempat dudukan daun yang terbentuk. Kandungan unsur hara dalam biourin kelinci diduga mempercepat pembelahan sel dalam pembentukan jumlah daun.. Pemberian biourin yang mengandung unsur hara makro berupa N, P, K, Mg dan Ca. Menurut Lingga (2010) unsur N sangat dibutuhkan tanaman untuk sintesa asam amino dan protein, terutama pada titik-titik tumbuh dan ujung-ujung tanaman sehingga mempercepat proses pertumbuhan tanaman yang menyebabkan terpacunya pembelahan sel dan pemanjangan sel sehingga akan mempengaruhi pertumbuhan tinggi tanaman. Bertambahnya jumlah sel pada bagian pucuk ini mengakibatkan bertambahnya tinggi tanaman bayam. Unsur $\mathrm{K}$ berperan sebagai aktifator dari berbagai enzim dalam reaksi fotosintesis dan respirasi, sedangkan unsur $\mathrm{Mg}$ berfungsi mengatur penyaluran zat karbohidrat dalam tubuh tanaman. Lingga (2010) menyatakan peran unsur $\mathrm{P}$ dan $\mathrm{Ca}$ dalam pengangkutan hasil metabolisme pada prosesa pembelahan sel tanaman dan memperbesar jaringan tanaman.

Biourin kelinci mengandung unsur $\mathrm{Mg}$ yang berfungsi sebagai penyusun klorofil sehingga unsur ini berperan penting terhadap pertumbuhan daun. Hal ini sesuai dengan pendapat Salisbury dan Ross (1992), Mg tidak hanya sebagai penyusun klorofil, $\mathrm{Mg}$ juga berfungsi dalam berbagai reaksi dan aktivator enzim dalam reaksi fotosintesis dan respirasi yang membentuk Adenosin Tri Posfat (ATP). Selanjutnya ditambahkan oleh Lakitan (2000) unsur Mg berfungsi sebagai penyusun klorofil sehingga mampu meningkatkan laju fotosintesis.

Berat basah dipengaruhi oleh jumlah serapan air dan hara pada suatu tanaman. Peran air bagi tanaman menurut salisbury (1995) sebagai komponen penting dalam proses fotosintesis dan respirasi tanaman. Proses penyerapan sangat berkaitan erat dengan sistem perakaran. Kandungan unsur hara $\mathrm{P}$, dan $\mathrm{Ca}$ dalam biourin kelinci mampu memenuhi pertumbuhan akar sehingga akar memiliki kemampuan baik dalam menyerap air dan hara. Menurut Novizan (2002) unsur $\mathrm{Ca}$ berperan dalam proses pembelahan sel dan mendukung kerja membran sel khususnya dalam transport hormon auksin menuju akar, hormon auksin berperan dalam mengaktifkan pompa ion pada plasma membran sehingga air masuk ke dalam sel yang menyebabkan pembesaran dan pemanjangan sel. Menurut Sutedjo (2010) mengatakan bahwa unusur $\mathrm{P}$ merangsang pertumbuhan akar sehingga dapat menyerap hara yang terkandung dalam tanah.

Berat kering salah satunya dipengaruhi oleh proses fotosintesis yang terjadi di daun, Semakin banyak dan lebar daun maka semakin banyak fotosintat yang dihasilkan dari proses fotosintesis. Menurut Salisbury \& Ross (1995), bahwa semakin banyak jumlah daunnya maka jumlah fotosintat yang terbentuk juga semakin banyak, fotosintat yang terbentuk nantinya akan disalurkan ke jaringan tumbuhan yang meliputi asam amino, protein, polisakarida dan lipid, keseluruhan bahan tersebut secara tidak langsung akan mempengaruhi massa suatu sel. Berat kering selain dipengaruhi adanya penambahan masa dari hasil fotosintesis juga dipengaruhi oleh adanya mineral atau unsur hara yang diserap oleh tanaman melalui akar dan daun. Menurut Prawiranata et al. (1981) unsur hara yang diserap oleh tanaman sangat berpengaruh berat kering tanaman. Novizan (2002) menambahkan bahwa unsur makro esensiasl berupa NPK dan $\mathrm{Ca}$ 
yang berperan penting dalam pembelahan sel dan pemanjangan sel, semakin bertambah jumlah sel maka berat kering massa tanaman juga semakin meningkat.

Rasio akar/tajuk diperoleh dengan membandingkan berat kering akar dan berat kering tajuk apabila perkembangan akar lebih aktif dari pada tajuk maka akan diperoleh nilai rasio akar/tajuk yang besar. Berat kering akar lebih tinggi dibandingkan berat kering tajuk menunjukkan tanaman memiliki pertumbuhan yang tidak baik. Menurut Sitompul \& Guritno (1995) semakin tinggi rasio perbandingan berat kering akar terhadap tajuk menunjukkan bahwa tumbuhan memiliki pertumbuhan yang tidak baik. Hal ini menunjukkan bahwa tanaman mengalami kekurangan air yang dibutuhkan tanaman untuk pertumbuhannya. Menurut Cambell et al. (1998) Rasio akar tajuk merupakan karakter yang dapat digunakan adanya kelebihan atau kekurangan air pada tanaman. Kelebihan air lebih menghambat pertumbuhan akar dibandingkan pertumbuhan tajuk sedangkan kekurangan air lebih menekan pertumbuhan akar dibandingkan pertumbuhan tajuk.

Faktor yang mempengaruhi pertumbuhan tanaman adalah faktor lingkungan yaitu $\mathrm{pH}$ tanah, suhu dan kelembaban udara. Berdasarkan pengamatan kisaran suhu dan kelembaban masih sesuai dengan perumbuhan bayam. Hasil pengamatan penelitian kisaran suhu dan kelembaban masing masing 26$53^{\circ} \mathrm{C}$ dan $43-58 \%$ menurut Bandini dan Aziz (2005) kisaran suhu diperlukan pertumbuhan bayam $20^{\circ}-30^{\circ} \mathrm{C}$ dan kelembaban $40-60 \%$. Tanah yang diuji memiliki pH 3,7 jika ditambahkan kapur dolomit 48,972 $\mathrm{g} \mathrm{CaCO}_{3} /$ polibag yang memiliki daya netralisasi $101,93 \%$, tanah menjadi $\mathrm{pH}$ 6,5. Nilai $\mathrm{pH}$ tanah masih memenuhi syarat hidup bayam berkisar 6-7 sehingga $\mathrm{pH}$ dikatakan sesuai dengan kondisi kebutiuhan hidup bayam. Menurut Sutarno (1988) bayam tumbuh dengan baik di tanah dengan derajat keasaman ( $\mathrm{pH}$ tanah) sekitar 6-7 karena ion-ion unsur hara terserap dengan optimal oleh tanaman pada $\mathrm{pH}$ yang ideal.

\section{DAFTAR PUSTAKA}

Afrianto, H, 2015, Pemanfaatan urin kelinci dan urin sapi sebagai alternatif pupuk organik cair pada pembibitan kakao (Theobroma cacao L.), Jurnal Kultivasi, vol 14, no 2

Bandini, Y \& Aziz, N, 1999, Bayam, Penebar Swadaya, Jakarta
Barchia, M, F, 2006, Gambut Agroekosistem dan Transformasi Karbon, UGM Press, Yogyakarta, hal 76-77

Cambell, Na, Reece, JB, Mitchell, LG, 'BIOLOGI Jilid 2', Erlangga, Jakarta

Chapelle, F, H, 2001, Ground-water Microbiology and Geochemistry, Jhon Wiley and Sons, New york

Djafar, TA, Asil, B, \& Syukri, 2013, 'Respon Pertumbuhan dan Produksi Sawi (Brassica juncea L.) Terhadap Pemberian Urin Kelinci dan Pupuk Guano', Jurnal Online Agroekoteknologi, vol. 18, no. 3

Gaspers, 1991, Metode Perancangan Percobaan, CV Armico, Bandung

Huda, MK, 2013, Pembuatan Pupuk Organik Cair dari Urin Kelinci dengan Aditif Tetes Tebu (Molasses) Metode Fermentasi, Skripsi, Universitas Negeri Semarang, Semarang, diakses $21 \quad$ Agustus 2017, <http://lib.unnes.ac.id/19689/1/4350408012.p df $>$

Hardjowigeno, S, 1996, Ilmu Tanah, Akademika Prerssiondo, Jakarta

Honing, 1963, Principle of Sugar Technology, Elsevier Publishing Company, New York, hal 56-57

Kurniadinata, F, 2008, Pemanfaatan Feses dan urin Sapi Sebagai Pupuk Organik dalam Perkebunan Kelapa Sawit (Elaeis guinensis Jacg.), Jurnal Pertanian, vol. 1, no. 2

Lingga, P, 2010, Petunjuk Penggunaan Pupuk, Penebar Swadaya, Jakarta hal 57-58

Lakitan, B, 2000, Dasar-dasar Fisiologi Tumbuhan, PT, Raja Grafindo Persada, Jakarta, hal 147148

Mardalena, 2007, Respon Pertumbuhan dan Produksi Tanaman Mentimun (Cucumis Sativus L.) Terhadap Urin Sapi yang Telah Mengalami Perbedaan Lama Fermentasi, Skripsi, Universitas Sumatera Utara Medan, Medan, diakses 13 Juli 2017, < https://mafiadoc.com>

Nugraheni ED \& Paiman, 2010, 'Pengaruh Konsentrasi dan Frekuensi Pemberian Pupuk Urin Kelinci Terhadap Pertumbuhan dan Hasil Tomat (Lycopersicum esculentum Mill)', Jurnal Agroteknologi, vol. 3, no. 2 hal. 10-11

Novizan, 2002, Petunjuk Pemupukan yang Efektif,. PT. Agro Media Pustaka, Depok, hal 65-68 
Noor, M, 2001, Pertanian Lahan Gambut Potensi dan Kendala, Kanisius, Yogyakarta

Nugroho, P, 2017, Panduan Membuat Pupuk Kompos Cair, Sri pertanian Bogor, Jakarta, hal 71-72

Prawiranata, WS, Haran \& Tjondronegoro, P, 1981, Dasar-dasar Fisiologi Tumbuhan, Institut Pertanian Bandung, Bogor

Parnata, A, S, 2004, Pupuk Organik Cair Aplikasi dan Manfaatnya, Agromedia Pustaka, Jakarta

Rukmana, R, 2010, Bayam, Penebar Swadaya, Bogor

Satiawihardja, 1992, Teknologi Pemanfaatan Limbah untuk Pakan: Fermentasi, diakses 30 Oktober 2017,<http://satiawihardjajajo66.files.wordpre ss.com $>$

Syarief, E S, 1985, Pupuk dan Cara Pemupukan Tanah Pertanian, Pustaka Buana. Bandung, hal 44

Suwahyono, U, 2017, Panduan Penggunaan pupuk Organik, Penebar Swadaya, Jakarta

Suriawira, U, 2010, Mikrobiologi Air, Rineka Cipta, Jakarta

Sutedjo, MM, 2010, Pupuk dan Cara Pemupukan, Rineka Cipta, Jakarta

Sunarjono, H, 2014, Bertanam 36 Jenis Sayur, Penebar Swadaya, Jakarta
Salisbury, JW \& Ross, 1995, Fisiologi Tumbuhan Jilid 2, Institute Teknologi Bandung, Bandung

Sutarno, H, 1988, Budidaya Bayam Biji, PT Bhrata Niaga Media, Jakarta

Sitompul, SM \& Guritno, B, 1995, Analisis Pertumbuhan Tanaman, Gadjah Mada University Press, Yogyakarta

Tisdale, SI, Nelson, W, I, \& Beaton, J, D, 1985, Soil Fertility and Fertilizer, Mac Millan Pub, New york

Utomo, AS, 2007, Pembuatan Kompos Dengan Limbah Organik, CV Sinar Cemerlang Abadi, Jakarta

Wijayasihati, SI \& Wigato, KW, 2016, 'Potensi Bayam Merah (Amaranthus tricolor L.) sebagai Antioksidan pada Toksisitas Timbal yang Diinduksi pada Mencit', Jurnal Kedokteran vol. 48 no. 2 , hal. $64-65$

Wijaya, KA, 2008, Nutrisi Tanaman sebagai Penentu Kualitas Hasil dan Resistensi Alami pada Tanaman, Prestasi Pustaka, Jakarta

Wiguna, J, 2010, 'Pengaruh Konsentrasi Pupuk Organik Cair Urin Kelinci dan Macam Pengajiran Terhadap Pertumbuhan dan Hasil Tanaman Mentimun (Cucumis sativus L.) Var. Bella F1', Jurnal Pertanian, vol. 36, no. 3 